УДК

94(497.11)"1941/1944"

316.728(497.11)"1941/1944"

Оригинални научни рад

Примљен: 18. 8. 2017.

Прихваћен: 22. 12. 2017.

\author{
Nataša MILIĆEVIĆ \\ Institute for Recent History of Serbia \\ natasa.milicevic@mts.rs
}

\title{
Ausweis, Guards and Borders: Travelling of the Middle Class in Occupied Serbia 1941-1944*
}

\begin{abstract}
This paper analyses the travelling of the Serbian citizens during the Nazi occupation. The special emphasis is placed on the travelling of the members of the Serbian middle class. It deals with different aspects of the issue: the restrictions imposed by the occupier, symbolically expressed through ausweis (personal documents, passes, and permits), guards and borders, motives for travelling, organization and security problems, types and forms of travelling, the structure of the citizens-travellers and the like. It also points to the difference between travelling within the borders of the country and travelling abroad.
\end{abstract}

Key words: Serbia, World War II, Nazi occupation, travelling, Serbian middle class, citizens, ausweis, guards, borders

Under the pressure of the war and occupation in Serbia in 1941, the daily life of the Serbian middle class as well as of all other layers of Serbian society fundamentally changed, just as it was the case in other parts of Europe under the domination of Nazi Germany. These changes also affected the field of travelling. The occupation changed both the travelling conditions and motives for travelling while the travelling itself became even more significant. When compared to the pre-war period, it became

* This article has been written within the framework of the scholarly project Serbs and Serbia in the Yugoslav and International Context: Internal Development and Position within European/Global Community (No 47027), financed by the Minisry of Education, Science and Technological Development Republic of Serbia. 
more difficult, more demanding and uncertain. It required extensive planning and overcoming of numerous restrictions and limitations imposed by the occupier and local authorities under occupation. The established borders were not only physical, political, ideological, spiritual, administrative and normative, but also time-related and symbolic. ${ }^{1}$ Piero Zanini said they also "marked a line between what could and could not be known, said or done; between what could be overcome, and what must not even be approached; between order, on one hand, and disorder on the other." ${ }^{2}$ During the years of occupation, the borders changed to suit the occupiers' needs, like the time borders, which determined the time for free movement or political border(s) between German allies in Yugoslavia, i.e. Serbia. The territory of Serbia was divided into four parts which were annexed to the occupation zones under the administration of Italy, Hungary, Bulgaria and Germany. Italy took most of Kosovo and Metohija, and later annexed them to a creation called "Greater Albania"; Hungary occupied and annexed Baranja and Bačka, and in October 1941, a newly established puppet state, the Independent State of Croatia (NDH) included the territory all the way to Zemun. The Greater Bulgaria annexed eastern and southern parts of Serbia with districts of Pirot, Vranje and Leskovac. The German occupation zone included the rest of Serbia: Banat, Kosovska Mitrovica district and two counties of the former Novi Pazar sandzak, as well as eastern Srem and Zemun. Thus, Serbia found itself in narrow, pre-1912 borders, under the strict regime of military administration, being obliged to pay contributions to the occupier and support the German occupation administration. ${ }^{3}$ In such a controlled area, the life of the Serbian middle class, as well as of other layers of society, was marked by the prohibition of organized gatherings in the streets, such as public manifestations, parades and group marches (without the permission of a German commander), the ban of listening to foreign radio stations, participation and work in political cultural, sports and other associations, as well as the ban of agitation, tearing of occupier's posters and pamphlets, and insulting the members of Vermaht, not to forget the forced labour, curfew, shooting anyone carrying arms or giving resistance to German forces, revenge for killing or

1 More on borders: Pjero Zanini, Značenja granice: prirodna, istorijska i duhovna određenja, (Beograd: Clio, 2002).

2 Ibid., 16.

3 Branko Petranović, Srbija u Drugom svetskom ratu 1939-1945, (Beograd: Vojnoizdavački i novinski centar, 1992), 111-113. 
wounding the German soldiers, shortage of basic foodstuffs, "black market", resistance and multiple civil war, the collaboration of a number of citizens with the occupier, the existence of agents, spies, riots, robberies and murders for personal and family reasons, etc. ${ }^{4}$ To move and travel under such conditions, the citizens needed a permit, which was issued by the occupier and Serbian authorities under the occupation. The permit was necessary if one wanted to cross the border between occupation zones, but it was also required for travelling from one district to another or from one municipality to another. It was not easy to get a permit to travel, or a permit for more or less unhindered movement, or as the Germans called it ausweis. It was equally difficult to get a permit issued by the Serbian authorities, which was called a travel permit. In this way, the occupation and local authorities controlled the travelling, as well as other life segments of the Serbian citizens. This was done not only by controlling their movement, but also by controlling traffic communications and means of transport. Therefore, the travelling of the Serbian middle class, as well as of other citizens, no matter if it was within the country or abroad, was under strict supervision. These political and administrative restrictions and control of movement should be added the variability of the military security situation or the material possibilities of the citizens themselves. They mostly travelled within the territory of Serbia under occupation, but also went abroad. Both types of travelling, as before the war, had their own specificities, which became even more pronounced under the war conditions. That is why they will be analysed separately. In case of travelling abroad, the paper will focus on the part of the road until the exit from the country.

However, these difficulties did not prevent the Serbian middle class from travelling nor did they diminish their desire and need to travel during the war period. They certainly did not travel without a strong reason. The reasons were similar to those before the war, but yet somehow different. Some of them travelled for work, others to get foodstuffs or medical treatment, some to escape from German or Serbian police pursuits, or simply because they wanted to move to a safer place. They even seemed to have travelled much more than before the war. Occasionally, it seemed the whole country was on the move. One contemporary noted that in the summer of 1941 the trains were "so crowded, that the German troops had to interfere and remove the redundant passengers, who hang from trains

$4 \quad$ Ibid., 132-133. 
just like from the trams in Belgrade some time before". ${ }^{5}$ Perhaps the explanation lies in the fact that, due to the control of traffic and the movement of people, it was much more spoken and written about. Different reports, newspaper articles, and memories regularly pointed out that the trains, ships and other means of transportation were packed with passengers. ${ }^{6}$ Some photographs dating from August 1943 testify of massive crowds at the Belgrade railway station. They show a number of travellers waiting for transport, while a large number of them could be seen on the roofs of freight trains. Among the passengers, there were peasants dressed in traditional costumes, middle class citizens wearing suits, as well as occupation officers in uniforms. ${ }^{7}$

Neither the middle-class nor other citizens in Serbia expected to travel safely and smoothly during the war period. This uncertainty was particularly noticeable during the uprising in the summer and autumn of 1941 when the travelling was disturbed and threatened by the attacks of the members of resistance movements to all traffic communications. To secure military and economic goals, the German occupation authorities forbade the passenger traffic in favour of freight traffic on Serbian railways. ${ }^{8}$ This measure was also justified by the Serbian authorities, who used the situation to denote the communists as the main culprits. Certain newspaper articles included a framed message of the following content: "If you cannot visit your family in the country, blame the communists, because they are obstructing normal traffic". ${ }^{9}$ Apart from the main railway, which functioned only from time to time, other routes did not function at all due to numerous sabotages. Belgrade was almost completely detached from the inland. The traffic on the railway between Belgrade and Valjevo

5 Archives of Yugoslavia (Arhiv Jugoslavije - AJ), Emigrant Government of the Kingdom of Yugoslavia (Emigrantska vlada Kraljevine Jugoslavije - EV) (103), 158-574, Извештај Делегата Краљевске владе за Блиски и Средњи исток о стању у земљи - Потпредседнику владе Слободан Јовановићу, Цариград, 27. 10. 1941.

6 „Путнички и теретни саобраћај успостављен са унутрашњошћу“, Ново време, 18. 12. 1941, 5; М. С., „Кад се Шабац претвара у Београд“, Српски народ, 24. 10. $1942,9$.

7 Биљана Станић, Фотографије Рите Марјановића 1941-1944, (Београд: Музеј града Београда, 2011), 165.

8 Дневни извештај Обавештајног одељења Команданта оружаних снага на Југоистоку од 1. новембра 1941 - Врховној команди Вермахта о борбама против партизана у Србији и Босни и о обостраним губицима, 1. 11. 1941, Zbornik dokumenta i podataka o narodnooslobodilačkom ratu naroda Jugoslavije (Zbornik NOR-a), XII-1, (Beograd: Vojnoistorijski institut, 1973), 558.

9 Ново време, 20. 10. 1941, 3; Понедељак, 3. 11. 1941, 4. 
in particular, was interrupted for a long time, and it was not until the middle of October 1941 that the traffic and travelling were enabled again. ${ }^{10}$ The circumstances were not much different on the railway from Belgrade towards Čačak and Užice, which was more than two months under the control of the rebels. A number of bridges were destroyed on the Morava River, near Mala Krsna, Stalać, and Jagodina; numerous bridges on the line Belgrade - Sarajevo, were also destroyed, as well as the facilities on the railway Stalać - Užice. ${ }^{11}$ Railway stations and trains were often under attack. The lives of passengers on passenger trains were also in danger. ${ }^{12}$ The roads were not safe either. They were destroyed, too. Therefore, according to the knowledge of a contemporary, probably shaped by unreliability and exaggerations, the German artillery regiment took ten days to cross fifty kilometres from Mladenovac to Belgrade. ${ }^{13}$ Travelling by ship was not advisable either. The rebels would force the passengers to leave the ships and then sink them. ${ }^{14}$ The middle-class members who had to travel or wanted to leave the regions under the control of the rebels travelled the way they could and knew. A good example was the travel of Stevan Žutić, the acting chief of financial department in Užice. On several occasions, he tried to leave the territory under the control of rebels and

10 Извештај 342. пешадијске дивизије од 1. новембра 1941 - Опуномоћеном команданту у Србији о војно-политичкој ситуацији код партизанских снага и код четника Драже Михаиловића у рејону Ваљево - Лозница, сарадњи са четницима Косте Пећанца и заробљеним немачким војницима, 1. 11. 1941, Zbornik NOR- $a$, XII- $1,569$.

11 AJ, 103-116-433, Запажања при путу од Београда до Цариграда, 1942. For more information, see: Петнаестодневни извештај Војнопривредног штаба Југоистока од 19.09.1941 - Врховној команди Вермахта ожелезничком, речном и путном саобраћају на територији Србије, Земун, 19. 9. 1941, Zbornik NOR-a, XII$1,419-422$.

12 Извештај 342. пешадијске дивизије од 1. новембра 1941 - Опуномоћеном команданту у Србији о војно-политичкој ситуацији код партизанских снага и код четника Драже Михаиловића у рејону Ваљево - Лозница, сарадњи са четницима Косте Пећанца и заробљеним немачким војницима, 1. 11. 1941, Zbornik NOR- $a$, XII-1, 569.

13 АJ, 103-116-433, Запажања при путу од Београда до Цариграда, 1942. - The above mentioned contemporary said it seemed that the distance between these two places was greater and that it was about eighty kilometers (Ibid.).

14 Дневни извештај Обавештајног одељења Команданта оружаних снага на Југоистоку од 1. септембра 1941 - Врховној команди Вермахта о акцијама партизана на територији Србије и о противмерама, 2. 9. 1941, Zbornik NOR-a, XII-1, 346-347; Петнаестодневни извештај Војнопривредног штаба југоистока од од 19. септембра 1941 - Врховној команди Вермахта о железничком, речном и путном саобраћају на територији Србије, Земун, 19. 9. 1941, Zbornik NOR-a, XII-1,419-422. 
return to Belgrade, but was stopped and arrested each time either by the Partisans or Chetniks (members of the Ravna Gora Movement). The arrests also included examining and proving the ideological-political stance, and the travelling itself included a series of dangers that jeopardized life. At one moment, at the beginning of October 1941, he arrived partly by train and partly on foot to the place between Čačak and Kragujevac where he was arrested again by Chetniks, and taken to Užice, which he left only after the fall of the uprising, at the end of November $1941 .{ }^{15}$

After the fall of the uprising in late 1941, the traffic was normalized and the citizens were able to start travelling regularly. ${ }^{16}$ The traffic, travelling and the safety of passengers were still disturbed by rebel groups or robbing parties, but never again to such an extent as in the autumn of 1941. The middle class still had to cope with uncertainties and difficulties of travelling. They were least concerned about the travelling comfort. It was important to reach the desired destination, finish what was planned and come back safely. Zvonimir Vučković wrote about the fear of passengers on trains attacked by Chetniks, between Belgrade and Čačak in the second half of 1942. It was not just a fear of Chetniks, but also the fear of the repression of the occupiers, because of taking away or injuring the German soldiers. On one occasion, when, after a train-attack, only German troops were taken away and other passengers released, they were relieved because they realized that nothing would happen to them. ${ }^{17}$ However, there were cases when the fears of passengers became reality. Thus, in an armed attack on a passenger train from Niš to Zaječar, a group of communists wounded a woman who travelled to Zaječar. ${ }^{18}$ Those who travelled by car also had hard time. Although a car was comfortable as a means of transport, it was not safe because it was often used by local pro-occupiers (government officials, businessmen, etc.) and attacked by

15 Military Archives (Vojni arhiv - VA), Nedić Archives (Nedićeva arhiva - Nda), 20-444, Записник саслушања Стевана Жутића, вишег секретара Министарства финансија и в. д., начелника финансијског одељења Банске управе Дунавске бановине у Ужицу од 24. децембра 1941.

16 „Путнички и теретни саобраћај успостављен са унутрашњошћу“, Ново време, 18. 12.1941, 5.

17 Звонимир Вучковић, Сећања из рата, (Крагујевац: Погледи, 2001), 246-247.

18 Државни телеграм Команде СДС, Зајечар - Команданту СДС (Опште одељење - Отсек ЈБ) - Београд, Команданту Нишке области СДС - Ниш, Зајечар, 11. 8. 1943, Извештаји Недићеве администрације и Српске државне страже за округ Зајечарски 1943-1944, 2, приредио Божидар Благојевић, (Неготин: Историјски архив Неготин - Зајечар: Историјски архив „Тимочка крајина“, 2007), 163. 
the members of the resistance movements. In the first months of the occupation, Teokarević brothers, the industrialists, who were shot while driving a car, felt this on their own skin. ${ }^{19}$ It should also be noted that it was not unusual that, after leaving a train or a bus, the passengers were attacked by the groups of robbers.

The attacks on traffic communications were not the only problem that made the travelling difficult. Due to new political and administrative borders Serbian citizens had to change the way of travelling. For example, after the border with the Independent State of Croatia was introduced, the citizens of Šabac were not able to travel by train to Belgrade, because it was leaving from the village Klenak, which belonged to the Independent State of Croatia. Therefore, during the occupation, they were forced to travel by cargo boats. In case of a low water level, they travelled by cart over Obrenovac, which had become very expensive since the beginning of the occupation. ${ }^{20}$ Every interruption of traffic between Belgrade and Šabac meant not only the lack of newspapers, information and other necessities, but also a kind of isolation of the city, which further encouraged the rumours and unreliable news. At the same time, the Belgraders who found themselves in Šabac had to stay longer than they planned and pay for their stay, which significantly reduced their funds. ${ }^{21}$ Those who wanted to travel from Belgrade to Zemun were also faced with problems. In the summer of 1941 they were issued border passes, and since October 1941, when Zemun became a part of the Independent State of Croatia, border passes in the form of permanent and daily permits for business travels or for family visits and meetings. They were issued by the Serbian authorities, with the consent of the German administration. One could reach Zemun by train, on foot, by ship or raft. ${ }^{22}$ Citizens who needed to cross the administrative border with Banat also experienced certain difficulties. They had to walk over the pontoon bridge or travel by boats, which crossed the Danube several times a day. Permits for crossing the river were granted by the German adminis-

19 АЈ, 103-5-51, Извештај Милоша Секулића о стању у Југославији - Комитету министара за пропаганду, Лондон, пов. бр. 257, 19. 11. 1941.

20 Григорије-Глиша Бабовић, Дневник 1941-1945, (Рума: Српска књига - Шабац: Глас Подриња, 2005), Забелешка од 15. маја 1941, 68, Забелешка од 10. септембра 1941, 123-124.

21 Ibid., Забелешка од 10. септембра 1941, 128.

22 Уредба о привременом уређењу малог граничног промета између пограничне зоне Београд са једне и пограничне зоне Земун, односно зоне Источног Срема с друге стране, 9. 10. 1941, Лист уредаба заповедника Србије, бр. 21, 10. 10. 1941; Ново време, 10. 10. 1941, 4. 
tration, and for walking over the bridge by the Serbian police authorities. ${ }^{23}$ As the time passed, the citizens wanted to visit their property more often and to get foodstuffs and to avoid the guards and controls, so they started using illegal crossings over the Danube River. ${ }^{24}$

Anyway, during and after suppressing the resistance, the German occupation and Serbian authorities significantly restricted the travelling conditions. New measures were introduced: clearing the ground around railway tracks, rail guards, traffic control by the Serbian police on the main tracks; wagons and trains were equipped with machine guns, handled by German troops. ${ }^{25}$ The railway protection south from Niš was taken over by Bulgarian forces. ${ }^{26}$ Beside ID cards, the middle-class as well as other citizens who travelled, needed permission for travelling ("special travel permits"). Initially, citizens were allowed to travel only with personal documents and passes. ${ }^{27}$ However, since 1942, no one was able to travel without a special travel permit. Those who arrived after the beginning of a police hour, also faced difficulties. They were not allowed to leave the railway or bus station without a pass. In the first months of occupation, they had to spend a night at the station or get a permit of the German administration at the station, if they lived in that place, so they could go home. ${ }^{28}$

23 Ново време, 20. 6. 1941, 6.

24 There were six illegal crossings: several crossings in Višnjica, Veliki selo, Vinča, Ritopek, Grocka and several crossings between Grocka and Smederevo (Historical archive of Belgrade (Istorijski Arhiv Beograda - IAB), Administration of the City of Belgrade (Uprava grada Beograda - UGB), Special Police (Specijalna policija - SP), к-141/17, Извештај V кварта УГБ - Управи града Београда, Одељењу специјалне полиције, 25. 2.1943).

25 Месечни извештај Оперативног одељења Команданта Србије од 5. 09. 1941. о акцијама партизана и дејствима сопствених јединица на територији Србије, 5 . 9. 1941, Zbornik NOR-a, XII-1, 358; AJ, 103-158-574, Извештај Краљевског делегата за Блиски и Средњи Исток - Председнику Владе, Цариград, 21. 10. 1941; Archive of Serbia (Arhiv Srbije - AS), Ministry of National Economy (Ministarstvo narodne ekonomije - G5), f-2, Уредба која се односи на заштиту саобраћаја на саобраћајним путевима и железничким линијама, 6. 11. 1941; VA, Nda, 28-530, Извештај Министарства унутрашњих послова, Команда Српске државне страже, Одељење безбедности - Команданту Београдске области, бр. 2161, 4. 8. 1942; Драган Алексић, Привреда Србије у Другом светском рату, (Београд: ИНИС, 2002), 222-223.

26 Седмодневни извештај оперативног одељења Опуномоћеног команданта у Србији од 10. новембра 1941 - Команданту оружаних снага на Југоистоку о војно-политичкој ситуацији у Србији, 10. 11. 1941, Zbornik NOR-a, XII-1, 616; Алексић, Привреда Србије, 223.

27 Општинске новине, 8. 5. 1941, 3.

28 Општинске новине, 18. 6. 1941, 3. 
The travel permits that were introduced at the beginning of 1942, after the fall of the uprising, were a way to limit movement. For most travellers who wanted to cross the border of a municipality, they were issued by the administrative and police authorities at the seat of the municipality, and for those who wanted to leave the borders of the county, the permits were issued by a county chief. ${ }^{29}$ However, they were not granted easily, as they needed a confirmation of the reasons for travelling and the duration of the journey. Thus, Dragoljub Ranković, a pensioner, was denied a permit several times when he mentioned the procurement of foodstuffs as a reasons for travelling from Belgrade to the country. ${ }^{30}$ This practically meant that without a permit, the middle-class travellers were not able to cross the administrative border of their municipality or county. Significantly simpler and easier was a procedure for those who worked as civil servants. They were issued the permits by the institutions in which they worked. They did not even have problems when it comes to private reasons for travelling. Furthermore, they had, as before the war, the benefits of travelling by train, which also applied to their family members. ${ }^{31}$ For merchants, however, there was a different procedure for permit granting. With the prior confirmation of the purpose of the trip, provided by the association to which they belonged, or the Chamber, they were issued a permit by an authorized police institution. ${ }^{32}$ They had the opportunity to get a "travel permit" for multiple trips and for the period of up to three months. ${ }^{33}$ Howev-

29 VA, Nda, 91-1-5, Наредба Министарства унутрашњих послова, Одељење за државну заштиту - Среском начелнику, бр. 11995, 19. 11. 1941; Ibid., Наредба Министарства унутрашњих послова о објавама за путовање, бр. 14736, 22. 12. 1941; Обнова, 25. 12. 1941, 7.

30 Свакодневни живот под окупацијом. Искуство једног Београђанина 1941-1944, приредили Наташа Милићевић и Душан Никодијевић, (Београд: ИНИС, 2011), Забелешка од 14. марта 1942, 174; Забелешка од 20. априла 1942, 203; Забелешка од 28. августа 1942, 322; Забелешка од 25. августа 1943, 594.

31 According to the railway regulations, civil servants had the right to an unlimited number of trips during the period of five years, while their family members had a benefit of 24 trips. Labourers and honorary officers were entitled to six trips, as well as members of their families (AS, Presidency of the Ministerial Council (G1), f-2, Акт Дирекције државних железница - Председништву Министарског савета, 12. 11.1942).

32 IAB, Leather Merchants Association 1942-1943, f-64, Распис и Упутство Трговинске коморе о путним објавама - Свим удружењима у Београду, бр. 14570, 1. 9. 1942; Ibid., Саопштење Трговинске коморе - Свим удружењима у Београд, бр. 14570, 8. 9. 1942.

33 The Chamber of Commerce and the UGB Special Police have long negotiated the conditions for obtaining these permits. In the end, a rather comprehensive Guide was 
er, it could not have been, at least formally, used for private trips; for that purpose, they needed an additional permit issued directly by the competent Serbian police authorities. ${ }^{34}$ However, there were periods and cities where neither middle-class nor other citizens could get permits or travel. Thus, in the second half of 1942, the Belgraders received information that the police would not issue permits, except in "special, emergency cases and under very strict conditions"; therefore, many were forced to travel even if they did not plan, to use the existing permits to finish some work. ${ }^{35}$ Bulgarian military authorities, who did not recognize travel permits issued by the Serbian authorities, caused a whole bunch of problems. Thus, the citizens of Kuršumlija could not get on train or leave the city if travel permits were not issued by the Bulgarian authorities, which, according to the agreement with the German administration, were not authorized to exercise police power. ${ }^{36}$

Most members of the middle class travelled for private purposes. This type of travelling included: buying foodstuffs, visiting relatives and family in the country or other towns, visiting property, going to a spa for medical treatment or rest, and the like. Considering the available sources, these travels were very numerous and frequent. However, the travelling for the acquisition of food stood out. Even when the main purpose of the trip was private or business, the food supply had a priority. Under the conditions of scarcity and poverty, it was an urgent need. That is why a senior official at the Ministry of Transport had to justify himself when control took away the food supplies from him. He said: "In the spare time, I was very often forced to travel to the country" in order to get supplies. ${ }^{37}$ There-

issued, listing all those who could get a travel permit with a three-month validity period. For example, they could have been issued to the members of the Steering Committees, company or shopkeepers, managers and employees, etc. (IAB, Leather Merchants Association 1942-1943, f-64, Распис и Упутство Трговинске коморе о путним објавама - Свим удружењима у Београду, бр. 14570, 1. 9. 1942).

34 IAB, Leather Merchants Association 1942-1943, f-64, Саопштење Трговинске коморе - Свим удружењима у Београду, бр. 14570, 8. 9. 1942.

35 Младен Жујовић, Ратни дневник 2. Југославија у II светском рату, (јун 1942април 1944), приредила Теодора Жујовић, (Врњачка Бања: Интерклима-графика, 2004), Забелешка од 24. 8. 1942, 44.

36 AS, Serbian State Commission for Determining Crimes of the Occupiers and Their Assistants (Zemaljska komisija Srbije za utvrđivanje zločina okupatora i njihovih pomagača - G25), f-16, Управа полиције у Нишу - Министарству унутрашњих послова, Одељењу државне заштите, 26. 5. 1942.

37 VA, Nda, 20A-6-46, Молба инг. Драгутина В. Марића - Министру саобраћаја, 3.6. 1942. 
fore, anyone who had the opportunity to travel, used this opportunity to buy and bring the necessary foodstuffs. However, German police authorities did not miss this fact. Because of the frequent trips of officials for private purposes, primarily the food supply, they sharply reprimanded the local authorities. ${ }^{38}$

Very often, travelling was not pleasant at all. In mid-September 1942, Mladen Žujović recorded that it was "a real torture to travel" by train "because it was overloaded with onions, plums, potatoes, beans and a few kilograms of hidden flour". ${ }^{39}$ Even worse was on small private ships and ships with a barge..$^{40}$ They were regularly crowded with passengers, so it was difficult to spend twelve hours, for example, travelling from Belgrade to Šabac $(105 \mathrm{~km}) .{ }^{41}$ Sometimes, the cargo ships would drift. Then, the trips lasted even longer. For Belgraders, who most often visited Šabac on weekends, the way back was much more difficult because they were carrying sacks, backpacks and bags filled with food, and there was much less space. ${ }^{42}$ Some middle-class members who travelled from Obrenovac to Belgrade were packed in cattle wagons, which were freezing during the winter period..$^{43}$ However, this hardly exhausted all the difficulties and traps of travelling. It was necessary to pass different types of guards and controls before, during and after the journey. The way back, in particular, could last for hours, as permits and quantity of foods were checked, not only by Serbian "tax collectors", but also by the German administration. ${ }^{44}$ After that, passengers were often left with no food and no money for new travels. Serbian middle class was exposed to other hazards, as well; one could never know who was sitting nearby and could hear an insufficiently cautious conversation between the travellers. Many diligent police agents or other citizens favouring the government of Milan Nedić used the oppor-

38 AS, G5, f-razno, Акт Министарства народне привреде - Одељењу за индустрију и занатство, пов. бр. 143, 14. 9. 1943.

39 Жујовић, Ратни дневник 2, Забелешка од 27. јануара 1942, 57.

40 They were significant for travelers who went to Zemun, Šabac, Pančevo, Smederevo, Donji Milanovac (Ново време: 16. 5. 1941, 6; 17. 5. 1941, 6; 9. 10.1941, 5).

41 М. С., „Кад се Шабац претвара у Београд“, Српски народ, 24. 10. 1942, 9; Милош Московљевић, Дневник 1916-1968, књ. 4, приређивач Момчило Исић, рукопис, Забелешка од 14. новембра 1943.

42 Ibid.

43 Бабовић, Дневник, Забелешка од 27. јануара 1942, 308.

44 VA, Nda, 59-5-5, Упутство Управе града Београда за службу полицијских стражара у циљу сузбијања комунистичке и друге разорне акције - Свим јединицама полицијске страже Управе града Београда, стр. бр. 10/41, 9. 1. 1942; Жујовић, Ратни дневник 2, Забелешка од 15. септембра 1942, 57. 
tunity to report this..$^{45}$ The middle-class travellers could also witness the incidents between members of the Serbian State Guard, volunteers and Chetniks at the railway stations or on trains including gun pulling which inevitably caused fear and panic among the passengers. ${ }^{46}$ The citizens who travelled for official or business reasons had similar experiences, except for the control. The exception were the journeys of the officials, especially those who occupied high positions in the local administration under occupation, as they were politically driven and carried out mainly by cars.

However, the middle-class members still travelled for rest and medical treatment, just as they did before the war. This type of travel depended on financial capability. That is why they most often went to visit relatives or friends in the country. It was both cheaper and more useful. Those who had to or had money also visited spa resorts in the country. Some media promoted certain spas, emphasizing their importance for rest and treatment of certain diseases. An associate of the newspaper Novo vreme stressed that it may not be appropriate to talk about tourist travel and tourism under occupation conditions, but that it was useful for the "state" and the population. He considered that travelling should not have been perceived as "caprice and luxury" practiced by wealthy individuals, but as a need of a "working man" for a break from everyday work and effort and a need to spend some time leisurely. He said one should take Germany as an example, where the organization "Kraft durch Freude" (Strength through Joy) systematically popularized the importance of travelling, going to other places and vacations.$^{47}$ Although the imposition of this topic in the Serbian public was not unusual, taking Germany as an example could have enticed the researchers. In his analysis of the mass cul-

45 Police agent Mirko Đikić reported Branislava Sutić from Belgrade due to an unfavorable comment on the personality of Milan Nedić. According to the report, when she saw the picture of Prime Minister Milan Nedić in the newspaper, she allegedly said: "This man is bad luck whenever I see him". Because she offended the personality of the Serbian Prime Minister, she was fined by the Special Police Department with ten days' imprisonment (VA, Nda, 131-3-4, Пријава против Мирка Ђикића, 10. 1. 1943; Ibid., Записник саслушања Браниславе Шутић у Одељењу специјалне полиције УГБ, 16. 1. 1943; Ibid., Пресуда Одељења специјалне полиције УГБ против Браниславе Шутић, бр. 390, 16. 1.1943).

46 VA, Nda, 26-10-2, Извештај командира Одељка страже железничке безбедности из Крушевца о изазивању панике у путничком возу пуцањем из пушака од стране добровољаца - Председништву Министарског савета и Команданту јавне безбедности, 12.10.1943.

47 Инж. Ратомир Стефановић, „Организовање туризма у Србији“, Ново време, 17.6. 1941, 3. 
ture, Kaspar Maase devoted a lot of attention to this issue. In addition to other activities, he said, the aforementioned organization arranged travels and trips at affordable prices for deprived workers and clerks, thus giving the Nazi an important instrument of control and indoctrination of individuals who could never, by then, organize their leisure time that way. ${ }^{48}$ Somewhat similar model was used in Serbia under German occupation. Soon, the spas were advertised as a new tourist destination. One of them offered "the most comfortable" stay in the famous hotel "Sotirović" in Vrnjačka Banja. ${ }^{49}$ By the end of June 1941, there were seven times less visitors in Vrnjačka Banja than in the previous year. ${ }^{50}$ Given the political and other circumstances that prevailed in Banja, it was understandable. The author of the article about this well-known and popular tourist destination emphasized that the conditions were not so favourable, especially if compared to the previous years. The offer of entertainment programme was poor. There was no more music until late into the night; instead, there were silence and peace and for those who wanted to come and rest or be treated, there were still a library and cinema. ${ }^{51}$ According to an advertisement, as early as in September 1941, just at the moment of the Uprising, it seemed that the offer in Vrnjačka Banja became much better: from treatment conditions over food and good accommodation to good traffic connections. ${ }^{52}$ Although it was somewhat surprising, it also testified of the tendency not to disturb the public and incite anti-occupational mood. The following year, the situation improved and the spas regained popularity and increased the number of visitors. ${ }^{53}$ Special attention was paid to Niška and Soko Banja, as places for rest and treatment. The report of July 1942 shows that Niška and Soko Banja, despite being expensive, were "full of guests" and that "guests were full of money". They hosted "many retired and active high-ranking officials of the Serbian state government", who acted quite extravagantly. They did not mind the fact that their behaviour influenced the "incredible increase" in prices of foodstuffs. This upset the officials responsible for suppressing the black market. They were even

48 Kaspar Maze, Bezgranična zabava: uspon masovne kulture 1859-1970, (Beograd: Službeni glasnik, 2008), 139-144.

49 Ново време, 29. 6.1941, 7.

50 This meant there were over 500 visitors (Ibid).

51 Ibid.

52 Ново време, 4.9.1941, 7.

53 Ново време, 31. 5. 1942, 6. 
asked to "turn a blind eye" during the season. ${ }^{54}$ At about the same time, writers Ivo Andrić and Rade Drainac were in Soko Banja for the treatment and rest. In his diary, Ivo Andrić noted that this region relieved problems with eyes, bones and blood circulation..$^{55}$ Unlike him, poet Rade Drainac, who suffered a severe form of tuberculosis, was forced to stay in the centre for treatment of this illness on Ozren Mountain for a long time. ${ }^{56}$

Members of Serbian middle class also travelled to escape the persecution of German and Serbian authorities and to flee to a safer place or go to the "forest" and join the partisan and Ravna Gora movements of resistance. The intention of this paper is not to discuss them in detail, they have already been written about, especially about the few citizens of Jewish origin, ${ }^{57}$ who fled from the cities. There was also a small group of middle-class travellers known to the German occupation and Serbian authorities by its communist and leftist ideas. ${ }^{58}$ However, it should be pointed out that their experience of organizing the journey itself and the route was different compared to that of previously mentioned middle-class travellers. Their lives were endangered because of their origin or previously known or recognized ideological determination, and for them the journey was a way to survive and continue the struggle. They could not travel without a fake ID and identity change, nor could they get on and off a passenger train. They could have been easily recognized or not pass the document control. Therefore, each successful check and passage was a moment when the fear turned to relief and a new hope of salvation. At the same time, getting

54 AS, Commissariat for Prices and Wages (Komesarijat za cene i nadnice - G6), f-119, Преглед окружних начелника о стању надзора над ценама и цене берзе у месецу јулу 1942.

55 Предраг Палавестра, „Андрићев дневник из Сокобање“, Свеске Задужбине Иве Андрића 14/1998, (Београд: Задужбина Иве Андрића, 1998), 19-25.

56 Ibid.

57 For more information, see: Милан Ристовић, „Прогоњени и њихови саучесници: солидарност и помоћ Јеврејима у Србији 1941-1944“, Израелско-српска научна размена у проучавању холокуста, Зборник радова с научног скупа, Јерусалим - Јад Вашем, 15-20. јуни 2006 = Israeli-Serbian academic exchange in holokaust research, Collection of paper from the academic conference, Jerusalem - Yad Vashem, 15-20. june 2006, Годишњак Музеја жртава геноцида - тематски број, ур. Јован Мирковић, (Београд: Музеј жртава геноцида, 2008), 169-208; Милан Ристовић, У потрази за уточиштем. Југословенски Јевреји у бекству од холокауста 19411945, (Београд: Службени лист СРЈ, 1998).

58 An excellent description of the atmosphere in the country through the train journey in 1941 was given by Petar Ristanović: Петар Ристановић, „Ужичка република у мемоаристици“, Војноисторијски гласник 2/2010, 115-139. 
on a train was burdened with concern for those who stayed. Mitra Mitrović remembered that she thought that her mother might not see her alive ever again, while Gojko Nikoliš thought of a pregnant wife, brothers and sisters. ${ }^{59}$ The communists were aware of the fact that by joining combat units, they exposed their closest relatives to possible arrests as hostages, but also that they might never see them again. However, one could still leave the city through "side channels" and avoid administration checks. Some stations did not have police controls. Therefore, one could get off on that station and walk to the next where there was no control and get on the train again. Belgrade, as the most populated city was in the centre of attention of local authorities, because one could easily hide there. Thus, the Communists and their sympathizers, and all citizens who wanted to avoid control, used the railway stations Senjak and Topčider to enter or exit Belgrade unnoticed. It was similar in other city centres. It seemed that the control in local trains was minimal. In smaller towns, it was a stop just before the entry of the train into the main station. ${ }^{60}$ However, there were other "channels" through which the the middle-class communists were able to leave Belgrade without documents. One "quite safe", which was used by the famous Ribnikar couple, led over Čukarica, where they were boarding cattle wagons. Otherwise, freight trains did not fall under control, so they were often used for the transfer of foodstuffs and the escape of those who were "nationally unfit" and "socially dangerous". They travelled to the next station, then walked across the Sava River and Srem to join the Partisans. ${ }^{61}$

Travelling abroad was different from travelling within the territory of the occupied Serbia. Those who were leaving had to cross the borders of the occupation zones, have the necessary documents, enough money, skill and personal luck. In the first weeks of the occupation of the country, a certain number of the Serbian middle-class members, primarily of Jewish origin, were hiding in the territories belonging to Italian, Bulgarian or Hungarian occupation zones, where a somewhat milder occupation regime prevailed. Shortly after the passing of the regulations against the Jews, they had fewer possibilities to leave the German occupation zone. However, this possibility, with all administrative, material and security barriers, still existed for those middle-class members who, for various reasons, fled or left the country (seeking safer places to live, establishing

59 Ристановић, „Ужичка република“, 117.

60 AS, Zbirka NOR-a (Ž28), f-6, Акт Начелства среза Јасеничког - Окружном начелству округа Београдског, пов. бр. 203, 6. 5. 1942.

61 Jara Ribnikar, Život i priča I-II, (Beograd: BIGZ, 1988), 60-61. 
links with the government in exile, performing political and intelligence tasks, health care, etc.). However, the 1941 uprising forced people to postpone the planned trips for safer times, due to the collapse of traffic communications and train attacks.

There were two ways for travelling abroad. One way led to the west through the Independent State of Croatia towards Italy, Spain, Portugal and, in particular, Switzerland, and the other to the east over Bulgaria to Turkey, Egypt and on. ${ }^{62}$ These countries, like in the case of Jewish refugees, were, to use the words of professor Milan Ristović, "transit stations." Travellers just wanted to pass by and leave them as quickly as they could, but that usually was not the case. ${ }^{63}$ In both cases, journeys were linked to numerous problems, which at first were not recognized as such, and brought about various complicated situations. It seems that, after the occupation, the middle class members more often opted for the east direction. It was, they thought, somewhat safer and faster way out of the country and to a safer territory. Compared to the west direction, where one had to cross several occupational zones and borders, and have a pass permit for each one, travelling to the east meant crossing from German to Bulgarian occupation zone and entering neutral Turkey. But, if they wanted to get to Great Britain, they had to go roundabout. At the beginning of the occupation, crossing from Serbia to Bulgaria required "no documents", not even a ticket, but only a permit issued by the German command, as recorded by Isak Alkalaj. ${ }^{64}$ Soon, the policy of leaving the country became much stricter.

Travelling required special and very carefully planned preparations that could take several months. After deciding where to go, most of the time, energy, and money was consumed for acquiring all the neces-

62 Milan Terzić points to the "western" and "eastern channel", through which information about the situation in the country reached the Yugoslav government in London. The "western channel" included Yugoslav diplomatic missions in Vatican, Portugal, Spain, Switzerland, and Sweden, and the "eastern channel" diplomatic missions in Turkey and Egypt. Again, this information was also gathered thanks to the Serbian middle-class citizens, who, after arriving and contacting diplomatic representatives, were asked to present their findings about the events in the country. For more information, see: Милан Терзић, „Југославија у виђењу Краљевске владе и Намесништва 1941-1945. Пропаганда и стварност“, (докторска дисертација, Универзитет у Београду, Филозофски факултет, Одељење за историју, 2004).

63 Ристовић, У потрази за уточиштем, 161.

64 Милан Ристовић, „Извештај врховног рабина Југославије др Исака Алкалаја о догађајима у Југославији од краја марта до краја јуна 1941. године“, Tokovi istorije 1-2/1997, 192. 
sary documents, passports, visas, etc. At the end of 1941, a number of middle-class travellers came in contact with criminals, who promised to provide them with the necessary documents for a certain, and not so small sum of money, without actually keeping the promise. ${ }^{65}$ There were bureaus selling counterfeit documents for exit from the country. Some of the ads in the second half of October 1941 offered help in filling out forms and travel passports. One of the ads said "Passports for all countries - form-filling, information, and instructions. Without waiting," and another, which offered the forms and "filling passports for trips." ${ }^{16}$ There were some middle-class travellers who at that time were ready to pay tens of thousands of dinars demanded by these bureaus for forged passports with required visas. ${ }^{67}$ However, according to one contemporary, these documents were, in most cases, "irregular even in form", and often those who sold such documents were at the same time agents of the Gestapo. Citizens did not only lose money at that time, they also ended up in prison. ${ }^{68}$ Thus, a planned journey ended even before it started. In any case, it was necessary to find reliable intermediaries, with good connections in German institutions. Most often, they were lawyers or other persons related to Germans and German administration. It can be said that issuing of such documents became a very lucrative and diversified business. Already at the end of 1941, the prices ranged from $100,000.00$ to $200,000.00$, only to be stabilized at about 200,000.00 dinars in the first half of $1943 .{ }^{69}$ For this amount, in the autumn of 1941, one could buy half of the house with one apartment and a parcel $\left(400 \mathrm{~m}^{2}\right)$ in Dimitrije Tucović Boulevard, and in some cases

65 АЈ, 103-186-653, Извештај о путу од Београда до Лондона секретара Министарства иностраних послова Војислава Божића - Министарству иностраних послова, Лондон, 15.3. 1943.

66 Ново време, 18. 10.1941, 9.

67 At that time, a forged Turkish passport with all necessary visas cost 80,000 dinars (AJ, 103-186-653, Извештај о путу од Београда до Лондона секретара Министарства иностраних послова Војислава Божића - Министарству иностраних послова, Лондон, 15. 3. 1943).

68 АЈ, 103-186-653, Извештај о путу од Београда до Лондона секретара Министарства иностраних послова Војислава Божића - Министарству иностраних послова, Лондон, 15. 3. 1943.

69 VA, EV, 162-1-21, Извештај Врховног комаданта, Начелника штаба, армијског ђенерала Богољуба Илића - Председнику Краљевске владе Д. Симовићу, Каиро 31. 12. 1941; AJ, 103-158-574, Препис извештаја из Каира о приликама у земљи, Лондон , 27. 2. 1942; АJ, 103-5-56, Телеграм Краљевског Посланства у Каиру Председништву Министарског савета, 10. 7.1943. 
even a whole house with three apartments on the outskirts of Belgrade. ${ }^{70}$ It was also an average four-year salary of a clerk. It is therefore clear that very few middle-class members were able to provide such a large amount of money for documents only. That's is why the travelling was a privilege of the rich middle-class citizens, who, in addition to strong social ties, had the opportunity to raise enough money to pay the lawyer and bribe German officials, but also for the journey itself. For all travellers, and especially middle-class travellers, it was better or easier if they had a document that showed that in the interwar period they had business and other ties with the Germans. Of course, a degree of courage was always needed in order to withstand various trials on the road. Among the travellers, there were lawyers, journalists, industrialists, large traders, senior officials, but also officers, as well as a few women. It should be mentioned that prior to obtaining visas, every citizen had to obtain a testimonial of the Belgrade City Administration that he was not of a "suspicious posture," which was obtained by submitting documents on the "correctness" provided by an institution or association (for example, the Chamber of Commerce). At the same time, the police of the Belgrade City Administration, inquired about the person travelling. It was only after that that the middle-class travellers were allowed to apply for German permission to leave the country and visas of other countries they had to pass through. ${ }^{71}$ They could even, in case they did not get a Turkish visa in Belgrade, apply for it in Sofia. For this, they needed a new mediator, whom they had to pay extra. ${ }^{72}$ For the citizens who were marked as "suspicious", mediators played a very important role. Let us mention, for example, the defence attorney and the reserve air force officer Dragoš Pavlićević, who was arrested more than once and actively cooperated with the resistance movement of Draža Mihailović. He could never get the necessary documents without the help of reliable and well-positioned persons in the occupation system. ${ }^{73}$ Industrialist Milan Dojčinović was an example of someone who relatively easy and fast, in just three months, got all the permits to leave the country. In addition to good connections and money, he had some previous business relations with German companies. This made German administration be-

70 Ново време, 26. 12.1941, 7-8.

71 АJ, 103-158-574, Препис извештаја из Каира о приликама у земљи, Лондон , 27. 2. 1942.

72 АЈ, 103-5-56, Телеграм Краљевског Посланства у Каиру - Председништву Министарског савета, 10. 7.1943.

73 Ibid. 
lieve that he was not of anti-German orientation and facilitated the procedure for obtaining the documents. ${ }^{74}$ Those who had a chance to go abroad for medical treatment, such as Dr. Vladislav Stakić, or were foreigners in marital relations with the Serbian citizens living in Serbia, such as the wife of painter Stojan Aralica, had a similar treatment. The former had to deliver a medical certificate, while the latter succeeded in securing the intervention of diplomatic representatives of their countries. ${ }^{75}$ There were also those citizens who were Serbian and Yugoslav citizens and used their origin (Muslim, Turkish or Bulgarian). Thus, Sabahadin Hodžić, an academic painter and cartoonist in Ošišani jež, with the help of a Turkish consul and the claim that he, as a Turk, wants to move to Turkey, acquired all the necessary documents for departure. ${ }^{76}$ Interestingly, the members of the middle class who legally, without paying mediators and forged documents, left the country, were "warned" that any kind of "indiscretion" on their part and statements regarding the state in the country could have "severe consequences" for their familiy and close relatives who stayed in the country. ${ }^{77}$ That is why, when meeting with Yugoslav diplomatic representatives and providing information on the situation in the country, they asked not to mention their names. Otherwise, they travelled by train from Belgrade to Sofia, which went only by day. As some citizens testify, at the end of 1941, they were "packed up with passengers", which was why they had to buy a ticket the day before. After the break of the uprising, the trains were guarded by German soldiers who were deployed at the beginning and the end of the train and armed with machine guns, and small cannons. The controls at the border, as noted by the contemporaries, were not strict, "the passports were only casually checked."78 From Sofia they went further towards Constantinople and Ankara, and then to Cairo, from

74 АJ, 103-158-574, Препис извештаја из Каира о приликама у земљи, Лондон, 27. 2. 1942.

75 АЈ, 103-160-582, Извештај Краљевског посланства у Стокхолму - Министарству иностраних послова КJ, 15. 3. 1942; АJ, 103-8-72, Писмо др Владислава Стакића - Председнику Министарског савета, Милошу Трифуновићу, Женева, 20. 7. 1943.

76 VA, EV, 162-1-21, Извештај Генералног конзулата у Цариграду КJ - Председнику Краљевске владе, армијском ђенералу Душану Симовићу, 31. 12. 1941.

77 АJ, 103-160-582, Извештај Краљевског посланства у Стокхолму - Министарству иностраних послова КJ, 15. 3. 1942; АЈ, Посланство Краљевине Југославије у Стокхолму (382), 1-3, Извештај Краљевског посланства у Стокхолму - Министарству иностраних послова КЈ, 15. 3.1942.

78 VA, EV, 162-1-21, Извештај Генералног конзулата у Цариграду КЈ - Председнику Краљевске владе, армијском ђенералу Душану Симовићу, 31. 12. 1941. 
where some of them went on a boat and, with the British permit, reached London.

The citizens who decided to use the western route were in a more difficult situation because they had to get, for example, a neutral Swiss or Portuguese permit to cross different occupation zones. But, if they wanted to travel to Italy, it was necessary, in addition to Germany, to have a special approval of the Italian Ministry of Foreign Affairs and the military commander of the occupation zone, through which they passed as well as Croatian passes issued by the diplomatic mission of NDH in Belgrade. ${ }^{79}$ Similar situation was with the German occupation zone in France, which required the permission of the military authorities. In any case, the available examples show that for travelling to the west for the purpose of medical treatment and recovery, but also for other reasons it was necessary to have the approval of the German administration (German passport). Some, like Dr Vojislav Stakić, were first in Italy, and then in Switzerland to treat a severe form of tuberculosis, ${ }^{80}$ while others, such as Radmila Djukić, a daughter of General Panta Djukić, went to Swiss health clinic. ${ }^{81}$ Unlike the seriously ill Stakić, Radmila Djukić intended to reach the UK. However, the Yugoslav government refused to help her, because it was afraid that this would not only endanger her relatives, but that it would also influence German approval for all other citizens who later wanted to come to the treatment and recovery. ${ }^{82}$ It is also interesting that her contacts with a Yugoslav diplomatic representative did not remain unnoticed. The German administration requested "to search her well" on her way back. ${ }^{83}$ It appears that, because she travelled with a German passport, she was followed by German representatives there. Having this in mind, it was not surprising that Živojin Perić, who came to Switzerland to see his children, refused to meet with Yugoslav diplomat Jurisić. He explained this by a very

79 АЈ, 103-186-653, Извештај о путу од Београда до Лондона секретара Министарства иностраних послова Војислава Божића - Министарству иностраних послова, Лондон, 15. 3. 1943.

80 АJ, 103-8-72, Писмо Војислава Стакића - Милошу Трифуновићу, председнику Министарског савета, Женева, 20.7.1943.

81 АJ, 103-8-72, Телеграм Председништва Министарског савета - Министарству иностраних послова, Лондон, пов. бр. 1063/IX/42.

82 Ibid.

$83 \mathrm{IAB}$, БдС/BdS (Заповедникполиције безбедности и службе безбедности / Befehlschaber der Sicherheitspolizei und Sicherheitsdeist Bds), D-449, Досије Радмиле Ђукић. 
comprehensive letter containing full legal interpretation of his status.$^{84}$ In addition to "ordinary" reasons - going to safer places, some citizens travelled for wider political and intelligence reasons. Therefore, some of these journeys were called missions. Among the familiar cases were the travels of the rich Belgrade family Bajloni. Its members (mother, two daughters and a son), with German permits, over the Independent States of Croatia and Switzerland, arrived to Portugal in October 1941. They brought a message from Draža Mihailović, the leader of one of the resistance movements, for the Yugoslav government in London. ${ }^{85}$ Their journeys, unlike the journeys of other middle class travellers, who made their own observations on the situation in the country, had a wider political significance in establishing the link between the resistance movements in the country and the government in exile.

In any case, middle-class members, as well as other citizens of Serbia, continued to travel under occupation - a lot. Travelling enabled them to gather, meet and socialize as well as to exchange information, goods and services. As before the war, the midde class travellers passed through various public spaces - railway and bus stations, trains, roads, etc. - but also urban and non-urban areas. For middle-class travellers, travelling became much more demanding and complex than in the period before the war. Whoever decided to travel had to count on facing and overcoming limitations and boundaries in order to reach the desired destination (financial possibilities, permits, military security situation, political and administrative boundaries, movement control regime, etc.). Among the motives, which varied, travelling for the acquisition of foodstuffs stood out. This was a priority even when the goal of the trip was, for example, official or business. Most often, they travelled to villages or towns with markets. It is interesting that the member of the middle class did not give up

84 АЈ, 103-88-336, Писмо Живојина Перића - посланику Јуришићу, 19. 9. 1941.

85 Milan Terzić, „Misija porodice Bajloni 1941“, Istorija 20. veka 2/2000, 59-66. - It should be noted that some trips of the middle-class citizens of Yugoslavia and Serbia had a clear political-intelligence character. Because of that, it could be, unlike the journey to the Bajloni family, where this just a secondary goal, called a missions. Among such trips are, for example, the trips of Stanislav Rapotec, a Slovenian, reserve lieutenant who traveled over Belgrade to Istanbul on two occasions with messages and notifications from the country. For more information, see: Stevan K. Pavlović, „Misije Stanislava Rapoteca 1941. i 1942, Jugoslovenski istorijski časopis 2/1997, 101-132; Milan Terzić, ,Još nešto o misijama Stanislava Rapoteca u Jugoslaviji 1941-1942“, Jugoslovenski istorijski časopis 1-2/2001, 117-126; Хедер Вилијамс, Падобранци, патриоти и партизани. Управа за спещијалне операције у Југославији 19411945, (Београд: Нолит, 2009). 
tourist trips. There were also well-known spas and health resorts. They mostly travelled within the territory of Serbia under occupation, but also went abroad. It is certain that the travelling of citizens under occupation was often deprived of personal satisfaction and that much was subject to the procurement of food and physical survival. We should not left out the benefits it had, under the conditions of strict censorship, regarding the exchange of information, getting to know how people live elsewhere, what problems they have, and so on. It created a sense of connectivity and influenced the exchange and unification of experiences in the struggle with everyday temptations.

\section{Sources and Literature}

\section{Unpublished sources}

- Archives of Yugoslavia. Funds: Emigrant Government of the Kingdom of Yugoslavia (103); The Mission of the Kingdom of Yugoslavia in Stockholm (382).

- Archive of Serbia. Funds: Presidency of the Ministerial Council (G1); Ministry of National Economy (G5); Commissions for prices and wages (G6); The State Commission of Serbia for determining the crimes of the occupiers and their assistants (G25); NOR collection (Ž28).

- Military Archive. Funds: Nedić's archive (Nda); Emigrant Government of the Kingdom of Yugoslavia (EV).

- Historical archive of Belgrade. Funds: Belgrade City Administration (UGB), Special Police (SP); Association of Skin Dealers 1942-1943; БдС/BdS (Commander of the Security and Security Services / Befehlschaber der Sicherheitspolizei und Sicherheitsdeist).

\section{Published sources}

- Бабовић, Григорије-Глиша. Дневник 1941-1945. Рума: Српска књига - Шабац: Глас Подриња, 2005.

- Вучковић, Звонимир. Сећања из рата. Крагујевац: Погледи, 2001.

- Жујовић, Младен. Ратни дневник2. ЈугославијауII светском рату, (јун 1942 - април 1944), приредила Теодора Жујовић. Врњачка Бања: Интерклима-графика, 2004.

- Z Zbornik dokumenta i podataka o Narodnooslobodilačkom ratu naroda Jugoslavije (Zbornik NOR-a), XII-1. Beograd: Vojnoistorijski institut, 1973. 
- Извештаји Недићеве администрације и Српске државне страже за округ Зајечарски 1943-1944, 2, приредио Божидар Благојевић. Неготин: Историјски архив Неготин - Зајечар: Историјски архив „Тимочка крајина“, 2007.

- Лист уредаба заповедника Србије, 1941.

- Палавестра, Предраг. „Андрићев дневник из Сокобање“. Свеске Задужбине Иве Андрића 14/1998, 19-25.

- Ribnikar, Jara. Život i priča I-II. Beograd: BIGZ, 1988.

- Свакодневни живот под окупацијом. Искуство једног Београђанина 1941-1944, приредили Наташа Милићевић и Душан Никодијевић. Београд: ИНИС, 2011.

Newspapers

- Ново време

- Српски народ

- Обнова

- Понедељак

- Општинске новине

Literature

- Алексић, Драган. Привреда Србије у Другом светском рату. Београд: ИНИС, 2002.

- Вилијамс, Хедер. Падобранци, патриоти и партизани. Управа за специјалне операције у Југославији 1941-1945. Београд: Нолит, 2009.

- Zanini, Pjero. Značenja granice: prirodna, istorijska i duhovna određenja. Beograd: Clio, 2002.

- Maze, Kaspar. Bezgranična zabava: uspon masovne kulture 18591970. Beograd: Službeni glasnik, 2008.

- Московљевић, Милош. Дневник 1916-1968, књ. 4, приређивач Момчило Исић, рукопис.

- Pavlović, Stevan K. „Misije Stanislava Rapoteca 1941. i 1942“. Jugoslovenski istorijski časopis 2/1997, 101-132.

- Petranović, Branko. Srbija u Drugom svetskom ratu 1939-1945. Beograd: Vojnoizdavački i novinski centar, 1992.

- Ристановић, Петар. „Ужичка република у мемоаристици“. Војноисторијски гласник 2/2010, 108-135. 
- Ристовић, Милан. У потрази за уточиштем. Југословенски Јевреји у бекству од холокауста 1941-1945. Београд: Службени лист CPJ, 1998.

- Ристовић, Милан. „Извештај врховног рабина Југославије др Исака Алкалаја о догађајима у Југославији од краја марта до краја јуна 1941. године“. Tokovi istorije 1-2/1997, 177-195.

- Ристовић, Милан. „Прогоњени и њихови саучесници: солидарност и помоћ Јеврејима у Србији 1941-1944“. Израелско-српска научна размена у проучавању холокуста, Зборник радова с научног скупа, Јерусалим - Јад Вашем, 15-20. јуни 2006 = IsraeliSerbian academic exchange in holokaust research, Collection of paper from the academic conference, Jerusalem - Yad Vashem, 15-20. june 2006, Годишњак Музеја жртава геноцида - тематски број, ур. Јован Мирковић, 169-208. Београд: Музеј жртава геноцида, 2008.

- Станић, Биљана. Фотографије Ристе Марјановића 1941-1944. Београд: Музеј града Београда, 2011.

- Терзић, Милан. „Југославија у виђењу Краљевске владе и Намесништва 1941-1945. Пропаганда и стварност“. Докторска дисертација, Универзитет у Београду, Филозофски факултет, Одељење за историју, 2004.

- Terzić, Milan. „Misija porodice Bajloni 1941“, Istorija 20. veka 2/2000, 59-66.

- Terzić, Milan. „Još nešto o misijama Stanislava Rapoteca u Jugoslaviji 1941-1942“. Jugoslovenski istorijski časopis 1-2/2001,117-126. 


\title{
Резиме
}

Наташа Милићевић

\section{Аусвајси, страже и границе: путовања грађана у окупираној Србији 1941-1944.}

\begin{abstract}
Апстракт: У раду се анализирају путовања грађана Србије за време нацистичке окупације. Посебан акценат стављен је на путовања припадника српског грађанства. Обрађени су различити аспекти тог питања: ограничења која је грађанима-путницима наметнула окупација, исказана кроз симболику аусвајса (личних исправа, пропусница, дозвола), стража и граница, затим мотиви за путовање, организациони и безбедносни проблеми, типови и облици путовања, структура грађана-путника и сл. Указано је и на специфичности које су имала путовања унутар земље и путовања ван земље.
\end{abstract}

Кључне речи: Србија, Други светски рат, нацистичка окупација, путовања, српско грађанство, грађани, аусвајси, страже, границе

Путовања грађана у рату и окупацији по Србији за време Другог светског рата била су, као и у предратном периоду, важан део њихове свакодневице. Може се рећи и да су, с обзиром на ограничења која је грађанима-путницима наметала окупација, постала још значајнија. Она су тада била тежа, захтевнија и неизвеснија. Захтевала су од грађана дуже припреме и превазилажење бројних ограничења и граница како би се спровела (материјалне могућности, дозволе за кретање, политичке и адмистративне границе, повољна војно-безбедносна ситуација и сл.). Услове и контролу путовања спроводиле су и окупаторска и домаћа власт под окупацијом преко строгог надзора кретања становништва, саобраћајних комуникација и превозних средстава. Издвајају се, с обзиром на услове путовања, два периода: први обухвата време устанка током 1941. године и недовољне безбедности путовања, када су путовања била и нередова и често одлагана, и други који обухвата период после слома устанка, када је, с једне стране, пооштрена контрола кретања грађана, а с друге дошло до успостављања редовности путовања, саобраћаја и боље безбед- 
ности путника. Међутим, без обзира на све препреке, грађани су наставили да путују. И то много. Путовања су им омогућавала сусрете, упознавања и дружења, али и размену информација, роба и услуга. Међу мотивима, који су разни и разноврсни, издвајају се, због оскудице у храни, посебно путовања ради набавке животних намирница. Она су добијала првенство и у случају када су циљеви путовања били неки други, на пример службени или пословни. Најчешће се путовало на село или у мање градске центре са пијацама. Занимљиво је и да грађани нису одустајали од туристичких путовања. Ишло се у од раније позната одмаралишта и лечилишта (Врњачка бања, Нишка или Соко бања). Путовало се највише унутар простора који је обухватала Србија под окупацијом, али се одлазило и у иностранство. Ова друга врста путовања била је специфична (прелазило се кроз неколико окупационих зона) и захтевала је дуготрајну припрему и сложену организацију путовања, у коју је спадало сакупљање потребних документа (пасоша, виза, и сл.), много новца, сналажљивости и личне среће. На такав пут ишли су углавном богатији припадници српског грађанства: адвокати, индустријалци, крупнији трговци, виши чиновници, али и официри, као и понека жена. У сваком случају, извесно је да су путовања грађана под окупацијом била често лишена личног задовољства и да су умногоме била подређена набавци животних намирница и физичком опстанку. Мада не треба изоставити ни корист коју су она, у условима постојања строге цензуре, пружала грађанима у погледу размене информација, упознавања са тим како живе људи изван места живљења, какви су им проблеми и др. То је стварало осећај повезаности и утицало је на размену и уједначавање искустава у борби са свакодневним искушењима. 